\title{
Floristic Composition of Groundcover Vegetation after the 2010 Pyroclastic Fire on Mount Merapi
}

\author{
Sutomo $^{1 *}$, Dini Fardila ${ }^{2}$ \\ ${ }^{1}$ Bali Botanic Garden, Indonesian Institute of Sciences (LIPI) Candikuning, Baturiti, Tabanan, Bali 82191, Indonesia \\ ${ }^{2}$ Biology Department, Syarif Hidayatullah State Islamic University Jakarta J1. Ir. H. Juanda No. 95 Ciputat, Tangerang, Banten \\ 15412, Indonesia
}

Received November 23, 2012/Accepted April 26, 2013

\begin{abstract}
Mount Merapi with its Merapi-type pyroclastic flows provides burnt and unburnt areas which are excellent to study establishment events of pioneer plant species. Using site comparison approach, floristic composition was studied, and thus an area that was burnt by pyroclastic flows in 2010 (Kalikuning) and another area that is relatively intact or unburnt (Kaliurang) was chosen as study sites. It found 7,817 individuals belonging to 72 species and 36 families in the burnt site, and 4,093 individuals belonging to 79 species and 39 families in the unburnt site. The most important family as determined by the family importance value (FIV) was Rubiaceae in Kalikuning and Asteraceae in Kaliurang. In terms of importance value index (IVI), Borreria occimoides (Rubiaceae) and Eupatorium riparium (Asteraceae) were the most important species in Kalikuning and Kaliurang, respectively. Multivariate approach using non-metric multidimensional scaling ordination technique showed that floristic composition in the newly burnt site were different with those that occupying the intact site $\left(R_{A N O S I M}=0.72\right)$. Borreria occimoides, Eupatorium riparium, Athyrium dilatatum, Paspalum conjugatum, Brachiaria reptans, and Selaginella doederleinii were the species mainly responsible in explaining the differences between sites.
\end{abstract}

Keywords: plant establishment, composition, diversity, secondary succession, Mount Merapi

*Correspondence author, email:sutomo.uwa@gmail.com, telp: +62-852-9008-7906

\section{Introduction}

One type of volcanic disturbance is pyroclastic flows (nuèes ardentes). Pyroclastic flows are hot turbulent gas and fragmented material resulting from a collapsed lava dome that rapidly moves down the volcanic slope and local people living near Mount Merapi named this phenomenon as wedhus gembel. (Dale et al. 2005a). The phenomenon of Merapi-type nuées ardentes in Mount Merapi volcano affects its forest areas. Fire as an integral part of volcanic disturbance has shaped community composition in montane forests of Java. The intense heat (often more than $700{ }^{\circ} \mathrm{C}$ ) released from nuées ardentes ignites wildfires.

Species establishment and composition changes is known as succession processes and volcanic disturbances can create this kind of processes (Walker \& del Moral 2003). Disturbance and recovery are 2 factors that play a significant role in the dynamics of a community and its species diversity (Connell \& Slatyer 1977; Crain et al. 2008). Establishment of invasive plant is interceded by disturbance (Hobbs \& Huenneke 1992). Disturbance and changes in plant communities have long been an interest among natural historians, foresters and ecologists (Smith 1914; McLean 1919). Disturbance is a key process that can affect diversity levels and change the community (Hobbs \& Huenneke 1992).
Citing Finegan (1984), Li et al. (1999) stated that many succession theories were based on intensive work in temperate forests. Gomez-Pompa and Vasquez-Yanes (1981) studied the succession that occurs in the tropics. However, their findings were based on the work on old fields and or in a lowland tropical forest. Other forest types such as volcanic tropical montane forest have received little attention (Tsuyuzaki \& Hase 2005; Whittaker et al. 1999). Furthermore, we are now acknowledging that 'one model fits all' is not appropriate for communities and ecosystems due to the complexity of the system (Hobbs et al. 2007). However, the scientific knowledge in this field is also inadequate, particularly in tropical montane forests, where scientific studies about the effects and the ecological consequences of disturbances at high-elevation are still scant (Horn et al. 2001).

Groundcover vegetation as one component of forest ecosystem plays an important role in ecosystem function. Groundcover species are more sensitive to disturbance compare to trees species. Research on tree species structure and composition has been conducted widely in Indonesia such as in Bukit Soeharto East Kalimantan (Syaukani et al. 2005). However, information regarding groundcover research following major disturbance is still scant (Sutomo et al. 2011). The pyroclastic flows burnt area found in Mount 
Merapi is relatively young, with the last event occurred in 2010. The objective of this study was to describe the patterns of groundcover plant recovery in the early secondary succession stage of the burnt areas on Mount Merapi. Using site comparison approach, an area that was burnt by pyroclastic flows in 2010 (Kalikuning) and another area that is relatively intact or unburnt (Kaliurang) was chosen as study sites (Figure 1). The research questions were:

1 does species composition and diversity on the newly affected site is different with the intact site?

2 which species contribute most to the differences in composition between the 2 sites?

The study provides information on dynamics of forest ecosystem during early secondary succession stage, which would be useful for managers working in the Mount Merapi National Park as a baseline data to consider when setting up reforestation and restoration program after volcanic disturbance.

\section{Methods}

The research was conducted in December 2011 to January 2012, approximately one year after the eruption and the research sites were located in the south-west flank forests of Mount Merapi, in the zone of the Mount Merapi National Park. Mount Merapi $\left(7^{\circ} 35^{\prime} \mathrm{S}\right.$ and $\left.110^{\circ} 24^{\prime} \mathrm{E}\right)$ is administratively located in 2 provinces, Central Java Province (Magelang, Boyolali, and Klaten Districts) and Yogyakarta Province (Sleman District). In Yogyakarta
Province, Mount Merapi is located approximately $30 \mathrm{~km}$ north of Yogyakarta.

Mount Merapi is representative of the landforms, soils, and vegetation on a volcanic mountain that typify a large portion of montane ecosystems in Java (Whitten et al. 1996). Based on Schmidt and Fergusson's climate classification (1951), the Merapi area is classified as type B (tropical monsoon area), which is characterized by a high intensity of rainfall in the wet season (November-March) with a dry season that can often be very dry without any rainfall (AprilOctober). Annual precipitation varies betwen 2,500-3,500 $\mathrm{mm}$ (BKSDA 2004). The variation of rainfall on Mount Merapi's slope is influenced by orographic precipitation. As in many other tropical monsoon areas, there are minor temperature and humidity variations during the year. Relative humidity on Mount Merapi varies from 70-90\%, with daily average temperatures is $19-30{ }^{\circ} \mathrm{C}$ (Forestry Agency DIY 1999). Soils of the study area are mainly of young volcanic-ash origin (regosol) with shallow and/or deep, low to medium fertility solums with a profile not yet developed (Darmawijaya 1990; BKSDA 2004).

An area of \pm 2.5 ha was chosen in each site. The 2 sites were located in a lower montane zone (Montagnini \& Jordan 2005). The canopies of the intact site in this study are dominated by the trees such as Altingia excelsa, Pinus merkusii, Casuarina junghuhniana, Schima walichii, and Swietenia mahagony, whereas the burnt site is mostly open area with some remaining dead trees, mostly $P$. merkusii and

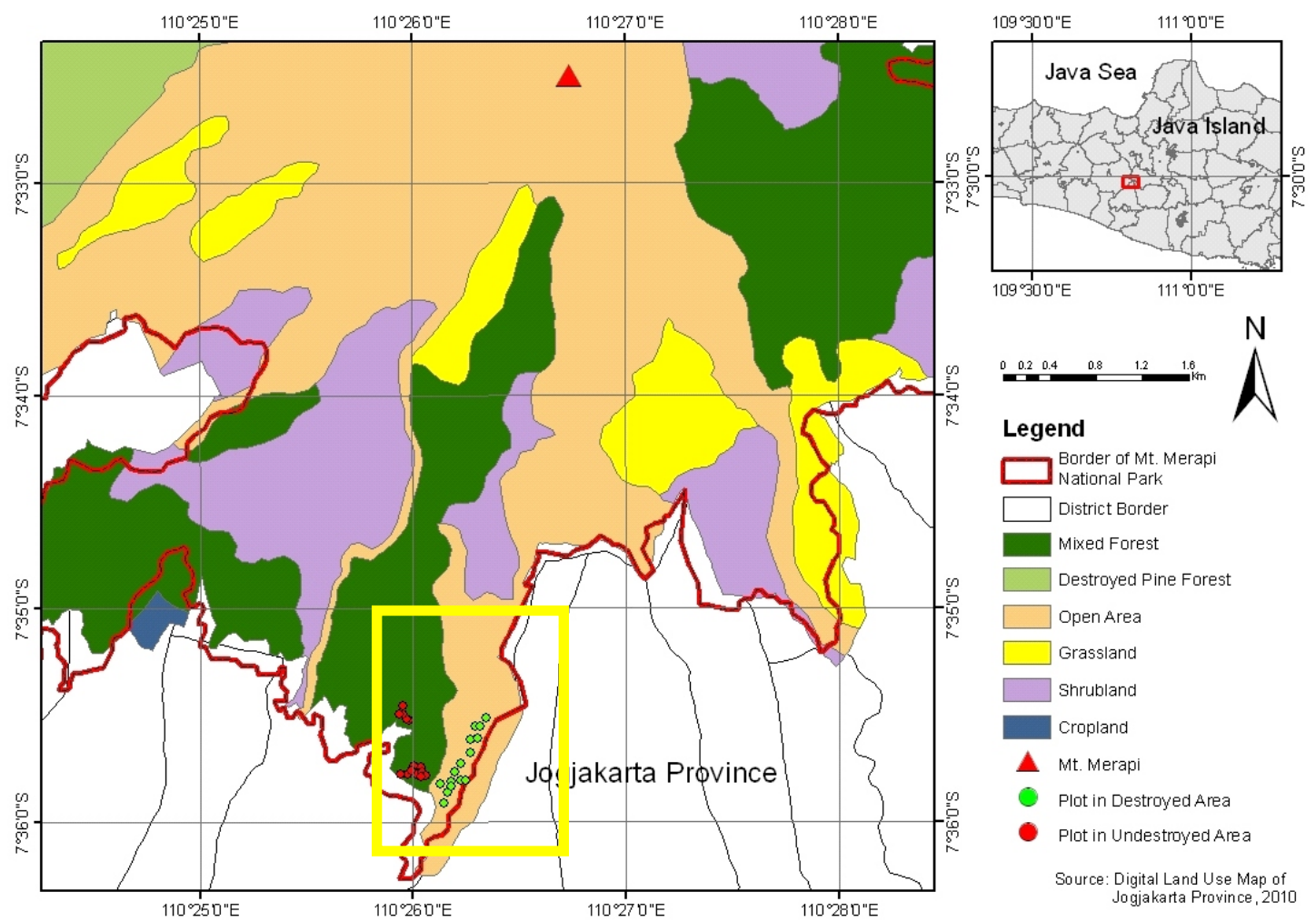

Figure 1 Map of sampling sites on Mount Merapi indicated by the dot points shapes. Green circles refers to affected sites by the pyroclastic flows (Kalikuning areas) whereas the red circles refers to intact site (Kaliurang). 


\section{A. excelsa.}

Fifteen circular plot 1 (5 m diameter) were sampled in each site (30 plots in total), assigned at random to grid cells on a map (Dale et al. 2005b). Each plot was located in the field with reference to a compass and a handheld global positioning system (GPS) Garmin E-Trex Legend. Herbs, shrubs, and tree seedlings abundance were measured as density, a count of the numbers of individuals of a species within the circular plot (Kent \& Coker 1992; Endo et al. 2008). Local plant name and latin name, when known, was noted. Whenever there was any doubt about species name, a herbarium sample was made. Drying and sample identification were done in Dendrology Laboratory, Faculty of Forestry, Gadjah Mada University. Vascular plant nomenclature is based on Backer and van den Brink (1963). Altitude was measured using a GPS and cross checked with 1: 25,000 topographic maps. A clinometer (Suunto PM-5 clinometer) was used to determine the slope (in degrees) (Le Brocque 1995).

A modified importance value index (IVI) for each species was calculated by summing its relative density and relative frequency in each plot, following Rasingam and Parthasarathy (2009). A modified family importance value (FIV) for each family was estimated as the sum of relative diversity and relative density of the individuals in that family. Species composition was compared among unburnt and burnt sites in order to examine the variation of undercover vegetation composition in response to pyroclastic fire.

The differences in community composition between deposits using data on species abundance (density) per plot were tested. The data was square root transformed (Valessini 2009) prior constructing resemblance matrix based on BrayCurtis similarity. Ordination diagram non-metric multidimensional scaling (NMDS) was then generated based on the resemblance matrix to show grouping of plots in each site and separation between different sites.

Variation in community composition between sites was subsequently tested for significance using one-way analysis of similarity (ANOSIM). ANOSIM is basically analogous to standard univariate ANOVA, and tests a priori defined groups against random groups in ordinate space. The $\mathrm{R}_{\mathrm{ANOSIM}}$ statistic values, generated by ANOSIM, are a relative measure of separation of the a priori defined groups. A zero $(0)$ indicates that there is no difference among groups, while one (1) indicates that all samples within groups are more similar to one another than any samples from different groups (Clarke 1993). The SIMPER routine in PRIMER V.6 was then used to explore the relative contribution of individual species to dissimilarity among deposits. All of these analyses were done using PRIMER v.6 software package (Clarke \& Gorley 2005).

\section{Results and Discussion}

Communities are never static, but dynamics due to the response to internal and external factors (Booth \& Swanton 2002). In the first year following wildfire from pyroclastic eruption, groundcover plant re-colonization on Mount Merapi was rapid. A total of 7,585 individuals and 42 species of herb were recorded in the burnt sites (Kalikuning) (Table 1). In addition, 176 individuals and 17 species of shrub, and 56 individuals and 13 species of tree seedling/sapling were recorded. Overall, 7,817 individuals of undercover plants belonging to 72 species and 36 families was recorded in the 15 plots of Kalikuning.

Based on species richness and abundance data, there were major differences in undercover vegetation composition between the burnt sites and the unburnt site or control site (Table 1). The number of herb species and individuals were significantly lower in Kaliurang (31 species and 2,392 individuals). In contrast, the number of tree species and individuals were higher in this unburnt site (30 species and 259 individuals). There was a similar number of shrub species in Kalikuning and Kaliurang, but the number of shrub individuals was significantly higher in Kaliurang.

The 5 most important herb and shrub species in Kalikuning accounted for $47 \%$ and $11 \%$ of the combined importance value, respectively. With a density of 134,658 individuals per hectare, Borreria occimoides (Rubiaceae) was the most frequent species, and consequently, holding the highest importance value of the undercover vegetation in Kalikuning (Table 2). Another most important species in this burnt site came from grasses group, such as Brachiaria reptans, Paspalum conjugatum, and Imperata cylindrica. Besides pioneer herbs and grasses, there was also seedling and sapling of woody species that was found. The proportion of the 5 most important tree species in Kalikuning was only $4 \%$ of the combined importance value. The configuration of tree species composition found in Kalikuning, for example A. decurrens, Calliandra callothyrsus, Homalanthus populnus, and $P$. merkusii, was resemble to what Sutomo et al. (2011) found in the succession sites following the 2006 Mount Merapi eruption.

Shrub and tree species in Kaliurang had a higher proportion of the combined importance value compared to in

Table 1 Number of individuals and species of herb, shrub, and tree seedling/sapling of undercover plants in the burnt site Kalikuning) and unburnt site (Kaliurang)

\begin{tabular}{lcccc}
\hline \multirow{2}{*}{ Habitus } & \multicolumn{2}{c}{ Number of species } & \multicolumn{2}{c}{ Number of individuals } \\
\cline { 2 - 5 } & Kalikuning & Kaliurang & Kalikuning & Kaliurang \\
\hline Herbs & 42 & 31 & 7,585 & 2,392 \\
Shrubs & 17 & 18 & 176 & 1,442 \\
Tree seedlings/saplings & 13 & 30 & 56 & 259 \\
\hline Total & 72 & 79 & 7,817 & 4,093 \\
\hline
\end{tabular}


Table 2 Density, frequency, and importance value index (IVI) of the top 5 important herb, shrub, and tree species in the burnt site (Kalikuning) and unburnt site (Kaliurang)

\begin{tabular}{|c|c|c|c|c|}
\hline Species & Family & Density (ind ha ${ }^{-1}$ ) & Frequency & IVI \\
\hline \multicolumn{5}{|c|}{ Herbs } \\
\hline \multicolumn{5}{|l|}{ Kalikuning } \\
\hline Borreria occimoides & Rubiaceae & 134,658 & 13 & 55.24 \\
\hline Brachiaria reptans & Poaceae & 20,858 & 12 & 12.04 \\
\hline Paspalum conjugatum & Poaceae & 15,253 & 10 & 9.23 \\
\hline Imperata cylindrica & Poaceae & 20,688 & 4 & 9.18 \\
\hline Polygala paniculata & Polygalaceae & 12,263 & 11 & 8.45 \\
\hline \multicolumn{5}{|l|}{ Kaliurang } \\
\hline Athyrium dilatatum & Polypodiaceae & 31,741 & 9 & 26.77 \\
\hline Selaginella doederleinii & Selaginellaceae & 6,518 & 11 & 9.49 \\
\hline Colocasia esculenta & Araceae & 3,972 & 10 & 7.23 \\
\hline Borreria occimoides & Rubiaceae & 6,416 & 3 & 5.93 \\
\hline Brachiaria reptans & Poaceae & 2,987 & 8 & 5.64 \\
\hline \multicolumn{5}{|c|}{ Shrubs } \\
\hline \multicolumn{5}{|l|}{ Kalikuning } \\
\hline Eupatorium riparium & Asteraceae & 1,936 & 9 & 3.87 \\
\hline Crotalaria micans & Fabaceae & 849 & 8 & 3.11 \\
\hline Impatiens platypetala & Balsaminaceae & 747 & 6 & 2.37 \\
\hline Anaphalis javanica & Asteraceae & 170 & 5 & 1.81 \\
\hline Paederia scandens & Rubiaceae & 442 & 4 & 1.56 \\
\hline \multicolumn{5}{|l|}{ Kaliurang } \\
\hline Eupatorium riparium & Asteraceae & 33,676 & 11 & 29.04 \\
\hline Impatiens platypetala & Balsaminaceae & 4,040 & 8 & 6.40 \\
\hline Clidemia hirta & Melastomataceae & 5,194 & 5 & 5.92 \\
\hline Cissus javana & Vitaceae & 1,222 & 9 & 4.81 \\
\hline Trichosanthes cucumeroides & Cucurbitaceae & 1,290 & 4 & 2.68 \\
\hline \multicolumn{5}{|c|}{ Tree seedlings/saplings } \\
\hline \multicolumn{5}{|l|}{ Kalikuning } \\
\hline Leucaena leucocephala & Fabaceae & 781 & 5 & 2.04 \\
\hline Acacia decurrens & Fabaceae & 306 & 5 & 1.86 \\
\hline Trema orientalis & Ulmaceae & 170 & 4 & 1.46 \\
\hline Calliandra callothyrus & Fabaceae & 136 & 3 & 1.10 \\
\hline Macaranga tanarius & Euphorbiaceae & 136 & 3 & 1.10 \\
\hline \multicolumn{5}{|l|}{ Kaliurang } \\
\hline Calliandra callothyrus & Fabaceae & 951 & 4 & 2.43 \\
\hline Maesa tetrandra & Myrsinaceae & 2,139 & 2 & 2.41 \\
\hline Thrinax radiata & Arecaceae & 475 & 4 & 2.09 \\
\hline Turpinia sphaerocarpa & Actinidiaceae & 1,018 & 3 & 2.04 \\
\hline Altingia excelsa & Altingiaceae & 373 & 3 & 1.58 \\
\hline
\end{tabular}

Kalikuning, accounted for $24 \%$ and $14 \%$, respectively. Eupatorium riparium (Asteraceae), an invasive species, was the most important shrub species in both Kaliurang and Kalikuning (Table 2). Two pteridophyte species, Athyrium dilatatum (Polypodiaceae) and Selaginella doederleinii (Selaginellaceae), were the top 2 herb species with the highest IVIs in Kaliurang, due to the highest number and frequency of individuals.

The 10 most important families made up $89 \%$ of the combined importance value in Kalikuning, and $70 \%$ of the total in Kaliurang. Asteraceae was the most species-rich family in both Kalikuning and Kaliurang (Table 3). However, in Kalikuning, Rubiaceae was the most important family with the highest FIV, due to its highest density. Poaceae was the second most important family in Kalikuning. Two fern families, Polypodiaceae and Selaginellaceae, were found in the top 5 most important families in Kaliurang. With respect to FIV, Rubiaceae, Asteraceae, Poaceae, and Euphorbiaceae were the families found in the top 10 in both Kalikuning and Kaliurang.

The composition differences of undercover plant species between the burnt and unburnt site is presumably due to their 
Table 3 The top 10 families with highest family importance value (FIV) in the burnt site (Kalikuning) and unburnt site (Kaliurang)

\begin{tabular}{lccc}
\hline \multicolumn{1}{c}{ Family } & No. of species & Density $\left(\right.$ ind ha $\left.^{-1}\right)$ & FIV \\
\hline Kalikuning & 17 & 135,100 & 56.80 \\
Rubiaceae & 51 & 78,335 & 47.27 \\
Poaceae & 56 & 8,730 & 22.80 \\
Asteraceae & 29 & 6,624 & 12.60 \\
Fabaceae & 26 & 4,824 & 10.88 \\
Cyperaceae & 11 & 12,263 & 8.45 \\
Polygalaceae & 18 & 3,431 & 7.56 \\
Euphorbiaceae & 11 & 3,465 & 5.14 \\
Polypodiaceae & 7 & 2,989 & 3.56 \\
Oxalidaceae & 4 & 2,955 & 2.51 \\
Cucurbitaceae & & & \\
Kaliurang & 25 & 36,246 & 36.99 \\
Asteraceae & 15 & 33,359 & 30.54 \\
Polypodiaceae & 24 & 14,709 & 21.06 \\
Poaceae & 11 & 6,522 & 9.49 \\
Selaginellaceae & 14 & 2,378 & 7.82 \\
Euphorbiaceae & 7 & 6,522 & 7.75 \\
Urticaceae & 10 & 3,975 & 7.23 \\
Araceae & 5 & 6,658 & 6.97 \\
Rubiaceae & 8 & 4,042 & 6.40 \\
Balsaminaceae & 5 & 5,197 & 5.92 \\
Melastomataceae & & &
\end{tabular}

different responses to abiotic factors such as differential light levels, nutrient availability, water availability, wind and temperature (Marquis et al. 1986; Denslow 1987; Laska 1997; Svenning 2000; Siebert 2002). The abundance and diversity of understory plants are also influenced by biotic factors. For example, birds, mammals, and bats are known to be important dispersers of pioneer and forest climax tree species, shrub, herb, and epiphytic species (GalindoGonzales et al. 2000; Siebert 2002). In the present study, herbs showed highest species richness and abundance in the open, burnt site, which is in accordance with the findings of Siebert (2002). The higher light levels and more open canopy in this land use type may explain the observations.

Ordination analysis on sampling sites based on species abundance data revealed that sampling points are distinctly separated between Kalikuning and Kaliurang (Figure 2). This phenomenon suggested that species composition and abundance are significantly different between these sites as tested by ANOSIM $\left(\mathrm{R}_{\text {ANOSIM }}=0.72\right)$. From the result we can also seen that the variation (within group dissimilarities) among sampling points in the control site is much larger than in the burnt site as showed by the more scattered patterns of the sampling points in the control site when compared to the burnt site where the sampling points are more clumped together. This phenomenon suggest that the control site is more developed than the burnt site where it is assumed that environmental condition in burnt site is quite similar each other following the pyroclastic flows whereas the control site has developed more varied niche. This finding agree with the findings of the configuration of NMDS ordination of burnt sites in Fraser Island dune sites Australia where sites with low frequency of fire are clearly separated with the high fire frequency and that site of low fire frequency has more plots variation than the high fire frequency site (Spencer \& Gregory 2006). Clear separation between Kalikuning and Kaliurang also suggests that the burnt and the control sites may have different environmental condition ignite different species to occupy, as will be exhibit from the result of the following SIMPER analysis.

Species that contributed most to the dissimilarity among sites was identified using SIMPER analysis (Table 4). SIMPER result revealed that the burnt site is mainly characterized by species such as B. occimoides, Paspalum conjugatum, Brachiaria reptans, Polygala paniculata, Cynodon dactylon, and I. cylindrica whereas the control site is characterized by species such as $E$. riparium, $A$. dilatatum, and $S$. doederleinii. Interesting points to note is that some species are strictly only occur in burnt site or in the control site. However, there are also species that occur on both sites but with different portion of abundance. These species either present at high abundance on one site and low abundance on the other site (B. occimoides, E. riparium, B. reptans, $P$. paniculata) but also there is species that present at almost equal abundance on both sites (C. dactylon).

Native pioneer species such as I. cylindrica appear only in the burnt site and absent in the control or unburnt site. This indicates that I. cylindrica is intolerant to shading and therefore it was present abundantly in the open space of the burnt site. In contrast, exotic pioneer such as E. riparium present in the two sites but with different abundance. $E$. 


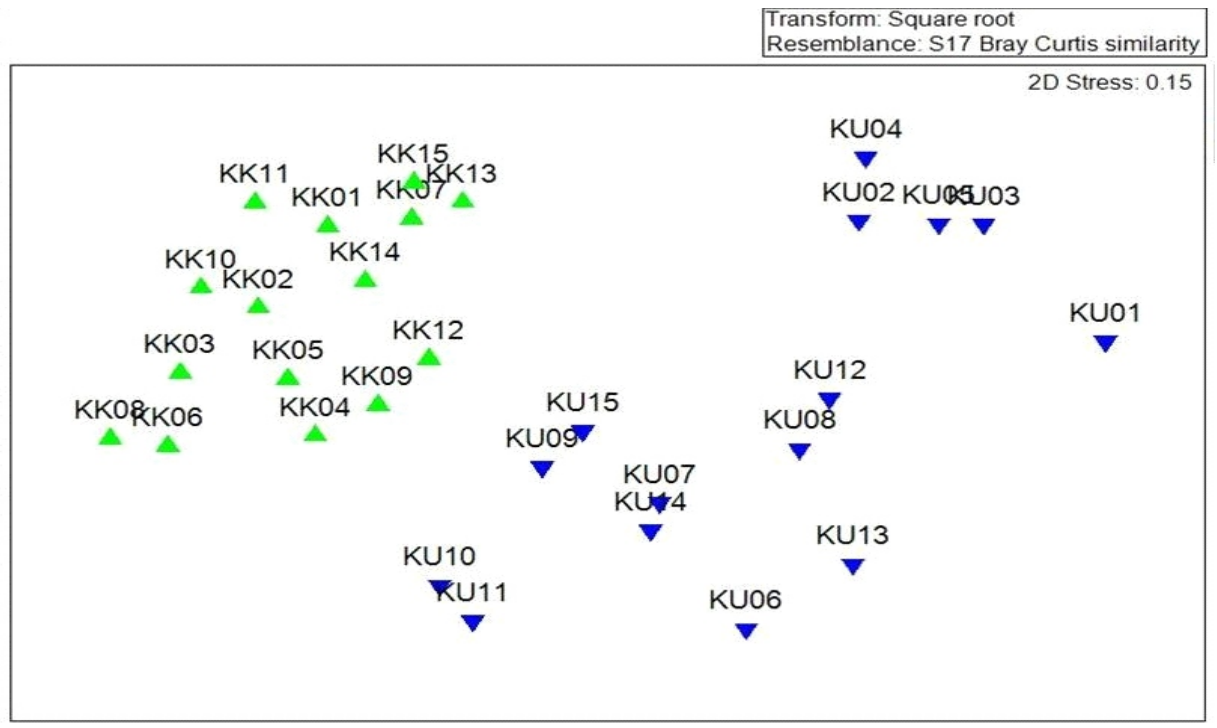

Figure 2 Plots ordination for the 2 study sites on Mount Merapi. Dark triangle refers to the affected site (KK = Kalikuning) and reverse light triangle refers to the intact site $(\mathrm{KU}=$ Kaliurang). Low $2 \mathrm{D}$ stress $(0.15)$ indicates good ordination figure representation, $\mathrm{R}_{\mathrm{ANOSIM}}=0.72$ indicates significance differences between the 2 sites.

Table 4 Similarity percentages (SIMPER) of differentiating species among habitat similarity comparison

\begin{tabular}{|c|c|c|c|c|c|c|}
\hline \multirow[t]{2}{*}{ Species } & Kalikuning & Kaliurang & \multirow[t]{2}{*}{ Av. diss } & \multirow[t]{2}{*}{ Diss/SD } & \multirow{2}{*}{$\begin{array}{c}\text { Contrib } \\
\%\end{array}$} & \multirow{2}{*}{$\begin{array}{c}\text { Cumulative } \\
\%\end{array}$} \\
\hline & Av. abund & Av. abund & & & & \\
\hline Borreria occimoides & 11.62 & 1.51 & 9.74 & 1.07 & 10.93 & 10.93 \\
\hline Eupatorium riparium & 1.42 & 6.19 & 5.19 & 1.11 & 5.83 & 16.76 \\
\hline Athyrium dilatatum & 0 & 4.4 & 4.16 & 0.83 & 4.67 & 21.43 \\
\hline Paspalum conjugatum & 4.09 & 0 & 3.86 & 1.07 & 4.33 & 25.76 \\
\hline Brachiaria reptans & 4.02 & 0.34 & 3.6 & 0.76 & 4.04 & 29.8 \\
\hline Selaginella doederleinii & 0 & 2.76 & 2.72 & 1.16 & 3.05 & 32.85 \\
\hline Polygala paniculata & 3.24 & 0.57 & 2.66 & 0.91 & 2.99 & 35.84 \\
\hline Cynodon dactylon & 1.85 & 1.65 & 2.4 & 0.9 & 2.69 & 38.53 \\
\hline Imperata cylindrica & 2.67 & 0 & 2.19 & 0.5 & 2.46 & 40.99 \\
\hline Pityrogramma calomelanos & 2.01 & 0.16 & 1.98 & 1.09 & 2.22 & 43.21 \\
\hline Colocasia esculenta & 0.13 & 1.98 & 1.84 & 0.97 & 2.07 & 45.28 \\
\hline Impatiens platypetala & 0.67 & 1.85 & 1.77 & 0.97 & 1.99 & 47.26 \\
\hline Clidemia hirta & 0.16 & 1.68 & 1.62 & 0.67 & 1.82 & 49.08 \\
\hline Arachis hypogea & 1.58 & 0 & 1.58 & 0.61 & 1.78 & 50.86 \\
\hline Crassocephalum crepidioides & 1.59 & 0.57 & 1.58 & 0.93 & 1.78 & 52.64 \\
\hline Phyllanthus urinaria & 1.74 & 0.68 & 1.58 & 1.06 & 1.78 & 54.41 \\
\hline Euchlaena mexicana & 1.71 & 0 & 1.55 & 0.6 & 1.74 & 56.16 \\
\hline Pennisetum purpureum & 1.43 & 0.48 & 1.43 & 0.89 & 1.6 & 57.76 \\
\hline Pteridium aquilinum & 0 & 1.47 & 1.4 & 0.37 & 1.57 & 59.33 \\
\hline Stenosemia aurita & 0.36 & 1.29 & 1.38 & 0.98 & 1.54 & 60.88 \\
\hline Oxalis corniculata & 1.52 & 0.35 & 1.36 & 0.94 & 1.53 & 62.41 \\
\hline Cyperus flavidus & 1.08 & 0.7 & 1.22 & 0.97 & 1.37 & 63.78 \\
\hline Brachiraria reptans & 0 & 1.29 & 1.2 & 0.69 & 1.34 & 65.12 \\
\hline Oplismenus compositus & 0 & 1.23 & 1.1 & 0.48 & 1.24 & 66.36 \\
\hline Ageratum conyzoides & 1.09 & 0.27 & 1.1 & 0.74 & 1.23 & 67.58 \\
\hline Gynura aurantiaca & 0.96 & 0 & 0.98 & 1.34 & 1.1 & 68.68 \\
\hline Cissus javana & 0.16 & 0.96 & 0.93 & 0.96 & 1.04 & 69.72 \\
\hline Cyperus melanospermus & 0.34 & 0.75 & 0.87 & 0.76 & 0.98 & 70.7 \\
\hline
\end{tabular}

Av. diss abbreviation refers to the average dissimilarity which is the average contribution for each species to the overall dissimilarity between groups. Diss/SD is the ratio of average dissimilarity with the standard deviation which indicates how consistent that a species contributes to dissimilarity among deposits. Cumulative contribution is the contribution of each species to the dissimilarity between the groups. 
riparium had higher abundance in the unburnt site suggesting that this species is tolerant to shading. E. riparium is an obnoxious weed that has become a problem elsewhere in the world (Kushwaha et al. 1981; Epp 1987; Kunwar 2003). This invasive species has the essential elements to establish and become wide spread and it has been identified in the succession sites following slash and burn agriculture in India (Kushwaha et al. 1981).

There are many quantitative and qualitative effects of disturbance to plant dynamics and these can have equally local and far reaching effects to the ecosystem (Spencer \& Gregory 2006). Severe disturbances have been an important component of tropical rain forest dynamics but comprehensive assessments of such events are inadequate (Whitmore 1991). Natural disturbances such as volcanic eruptions, hurricanes, and wildfires can catastrophically change the ecosystem over a short time scale (Scheffer et al. 2001). However, despite the fact that wildfires from pyroclastic flows can have a large impact on plant communities, it has received scant attention (Marti \& Ernst 2005). Understanding the dynamics of forest ecosystems during succession and how they interact with disturbances will be an important component of forest ecosystem conservation and restoration practices (Hobbs et al. 2007; Swamy et al. 2000).

\section{Conclusion}

The observation of undercover plant establishment pattern in primary succession on Mount Merapi revealed that there was a rapid colonization by vascular plants on the area that was affected by 2010 pyroclastic flows, with 72 species belonging to 36 families recorded. Species abundance and composition in Mount Merapi were significantly different between the burnt site and the intact site. The areas that was burnt by pyroclastic flows were dominated by herb and grass species such as $B$. occimoides, $B$. reptans, $P$. conjugatum, and I. cylindrica, whereas the unburnt site was dominated by shrub and fern species such as E. riparium, A. dilatatum, and $S$. doederleinii. This result could have important value for restoration programs, which could concentrate on re-planting subsequent species that have positive association with these native pioneer species.

\section{Acknowledgements}

This research was funded by the Rufford Small Grants for Nature Conservation. We would like to thank Josh Cole and Jane Raymond at the Rufford Small Grants Foundation, Soewarno HB MS from the Faculty of Forestry Gadjah Mada University, Kuspriyadi Sulistyo, the Head of the Merapi National Park (BTNGM) for permission to enter the national park and conduct the field data collections, to Gunawan and Dina Anggraini for field assistance, and lots of other kind helps that could not be mention here.

\section{References}

Backer CA, van den Brink RCB. 1963. Flora of Java. Leiden: The Rijksherbarium.

[BKSDA] Nature Resource Conservation Agency. 2004. Rencana Pengelolaan Taman Nasional Gunung Merapi
Periode 2005-2024. Nature Resource Conservation Agency, Indonesian Ministry of Forestry.

Booth BD, Swanton CJ. 2002. Assembly theory applied to weed communities. Weed Science 50: 2-13. http://dx.doi.org/10.1614/0043-1745(2002)050[0002: AIATAT]2.0.CO;2.

Clarke KR. 1993. Non-parametric multivariate analyses of changes in community structure. Australian Journal of Ecology 18: 117-143. http://dx.doi.org/10.1111/j.14429993.1993.tb004 38.x.

Clarke KR, Gorley RN. 2005. PRIMER: Plymouth Routines in Multivariate Ecological Research. Plymouth: PRIMER-E Ltd.

Connell JH, Slatyer RO. 1977. Mechanisms of succession in natural communities and their role in community stability and organization. The American Naturalists 111: 1119-1144. http://dx.doi.org/10.1086/283241.

Crain CM, Albertson LK, Bertness MD. 2008. Secondary succession dynamics in estuarine marshes across landscape-scale salinity gradients. Ecology 89: 28892899. http://dx.doi.org/10.1890/07-1527.1.

Dale VH, Acevedo JD, MacMahon J. 2005a. Effects of modern volcanic eruptions on vegetation. In: Marti J, Ernst G, editors. Volcanoes and the Environment. New York: Cambridge University Press. http://dx.doi.org/ 10.1017/CBO9780511614767.009.

Dale VH, Swanson FJ, Crisafulli CM. 2005b. Disturbance, survival and succession: understanding ecological responses to the 1980 eruption of Mount St. Helens. In: Dale VH, Swanson FJ, Crisafulli CM, editors. Ecological Responses to the 1980 Eruption of Mount St. Helens. New York: Springer. http://dx.doi.org/10. 1007/0-387-28150-9_1.

Denslow JS. 1987. Tropical rainforest gaps and tree species diversity. Annual Review of Ecology and Systematics 18: 431-451. http://dx.doi.org/10.1146/annurev.es. 18.110187.002243.

Endo M, Yamamura Y, Tanaka A, Nakano T, Yasuda T. 2008. Nurse-plant effects of a dwarf shrub on the establishment of tree seedlings in a volcanic desert on Mount Fuji, Central Japan. Arctic Antarctic and Alpine Research 40: 335-342. http://dx.doi.org/10.1657/15230430(07-013)[ENDO]2.0.CO;2.

Epp GA. 1987. The seed bank of Eupatorium odoratum along a successional gradient in a tropical rain forest in Ghana. Journal of Tropical Ecology 3: 139-149. http://dx.doi.org/10.1017/S0266467400001887.

Finegan B. 1984. Forest succession. Nature 312: 109-114. http://dx.doi.org/10.1038/312109a0. 
Galindo-Gonzales J. Guevarra S, Sosa VJ. 2000. Bat and bird generated seeds rains at isolated trees in pastures in a tropical rain forest. Conservation Biology 14(6): $1693-$ 1703. http://dx.doi.org/10.1046/j.1523-1739. 2000. 99072.x.

Gomez-Pompa A, Vazquez-Yanes C. 1981. Successional studies of a rain forest in Mexico. In: West DC, Shugart HH, Botkin DB, editors. Forest Succession: Concepts and Application. New York: Springer-Verlag. http://dx.doi.org/10.1007/978-1-4612-5950-3_16.

Hobbs RJ, Huenneke LF. 1992. Disturbance, diversity and invasion: Implication for conservation. Conservation Biology 6: 324-336. http://dx.doi.org/10.1046/j.15231739.1992.06030324.x.

Hobbs RJ, Jentsch A, Temperton MV. 2007. Restoration as a process of assembly and succession mediated by disturbance. In: Walker RL, Walker J, Hobbs RJ, editors. Linking Restoration and Ecological Succession. New York: Springer. http://dx.doi.org/10.1007/978-0-38735303-6_ 7.

Horn SP, Kennedy LM, Orvis KH. 2001. Vegetation recovery following a high elevation fire in the Dominican Republic. Biotropica 33: 701-708.

Laska G. 1997. Species adaptations and their importance in transformations of secondary plant communities. Ekologia Polska 45(2): 495-529.

Kent M, Coker P. 1992. Vegetation Description and Analysis: A Practical Approach. New York: John Wiley and Sons.

Kunwar RM. 2003. Invasive alien plants and Eupatorium: Biodiversity and livelihood. Himalayan Journal of Science 1: 129-133.

Kushwaha SPS, Ramakrishnan PS, Tripathi RS. 1981. Population dynamics of Eupatorium odoratum in successional environments following slash and burn agriculture. Journal of Applied Ecology 18: 529-535. http://dx.doi.org/10.2307/2402414.

Le Brocque AF. 1995. Vegetation and environmental patterns on soils derived from Hawkesbury Sandstone Narrabeen substrata in Ku-ring-gai Chase National Park, New South Wales. Australian Journal of Ecology. 20: 229238. http://dx.doi.org/10.1111/j.1442-9993.1995.tb005 34.x.

Li X, Wilson SD, Song Y. 1999. Secondary succession in two subtropical forests. Plant Ecology 143: 13-21. http://dx.doi.org/10.1023/A:1009806512601.

Marquis RJ, Donnelly MA, Guyer C. 1986. Aggregations of calling males of Agalychnis calcarifer Boulenger (Anura: Hylidae) in a Costa Rican lowland wet forest.
Biotropica 18(2): 173-175. http://dx.doi.org/10. 2307/2388762.

Marti J, Ernst G. 2005. Volcanoes and Environment. New York: Cambridge University Press. http://dx.doi.org/ 10.1017/CBO9780511614767.

McLean RC. 1919. Studies in the ecology of tropical rain forest: With special reference to the forest of South Brazil. The Journal of Ecology 7: 5-54. http://dx.doi.org/10.2307/2255704.

Montagnini F, Jordan CF. 2005. Tropical Forest Ecology: The Basis for Conservation and Management. Berlin: Springer.

Rasingam L, Parthasarathy N. 2009. Diversity of understory plants in undisturbed and disturbed tropical lowland forests of Little Andaman Island, India. Biodiversity and Conservation 18: 1045-1065. http://dx.doi.org/10. 1007/s10531-008-9496-z.

Scheffer M, Carpenter S, Foley JA, Folke C, Walker B. 2001. Catastrophic shifts in ecosystems. Nature 413: 591596. http://dx.doi.org/10.1038/35098000.

Siebert L, Simkin T. 2002. Volcanoes of the World: an Illustrated Catalog of Holocene Volcanoes and their Eruptions. Smithsonian Institution, Global Volcanism Program Digital Information Series, GVP-3, (http://www.volcano.si.edu/gvp/world/).

Smith WG. 1914. Notes on Danish vegetation. The Journal of Ecology 2: 65-70. http://dx.doi.org/10.2307/ 2255588 .

Spencer RJ, Gregory SB. 2006. Effects of fire on the structure and composition of open eucalypt forest. Austral. Ecology 31: 638-646. http://dx.doi.org/ 10.1111/j.1442-9993.2006.01616.x.

Svenning MA. 2000. Growth of Atlantic salmon parr in fluvial and lacustrine habitats. Journal of Fish Biology. 57(1):145-160.

Sutomo, Hobbs RJ, Cramer VA. 2011. Plant community establishment on the volcanic deposit following nuees ardentes of Mount Merapi: diversity and floristic variation. Biodiversitas 12: 86-91.

Swamy PS, Sundarapandian SM, Chandrasekar P, Chandrasekaran S. 2000. Plant species diversity and tree population structure of a humid tropical forest in Tamil Nadu, India. Biodiversity and Conservation 9: 16431669. http://dx.doi.org/10.1023/A:10265 11812878.

Syaukani HR, Kusmana C, Alikodra HS, Darusman D, Mudikdjo K. 2005. Forest structure and species composition in Taman Raya Bukit Soeharto, East 
Kalimantan. Jurnal Manajemen Hutan Tropika 11(1): $157-66$

Tsuyuzaki S, Hase A. 2005. Plant community dynamics on the volcano Mount Koma, Northern Japan, after the 1996 eruption. Folia Geobotanica 40: 319-330. http://dx.doi.org/10.1007/BF02804282.

Valessini F. 2009. NBIO528 Multivariate Techniques and Community Ecology: Course Handout. Perth: Centre for Fish and Fisheries Research Murdoch University.

Walker RL, del Moral R. 2003. Primary Succession and
Ecosystem Rehabilitation. Cambridge: Cambridge University Press. http://dx.doi.org/10.1017/CBO978 0511615078 .

Whitmore TC. 1991. Tropical rain forest dynamics and its implications for management. In: Pompa GA, Whitmore TC, Hadley M, editors. Rain Forest Regeneration and Management . France: UNESCO.

Whittaker RJ, Partomihardjo T, Jones SH. 1999. Interesting times on Krakatau: Stand dynamics in the 1990s. Philosophical Transactions: Biological Sciences 354: 1857-1867. http://dx.doi.org/10.1098/rstb.1999.0527. 